\title{
Effects of C-Peptide Replacement Therapy on Bone Microarchitecture Parameters in Streptozotocin-Diabetic Rats
}

\author{
Samantha Maurotti ${ }^{1}$. Cristina Russo ${ }^{2} \cdot$ Vincenzo Musolino $^{3}$. Saverio Nucera ${ }^{3} \cdot$ Micaela Gliozzi $^{3}$. \\ Miriam Scicchitano ${ }^{3}$. Francesca Bosco ${ }^{3}$. Valeria Maria Morittu ${ }^{4}$. Monica Ragusa ${ }^{4}$ Elisa Mazza ${ }^{1}$. Roberta Pujia ${ }^{1}$. \\ Carmine Gazzaruso ${ }^{5}$. Domenico Britti ${ }^{4} \cdot$ Maria Teresa Valenti $^{6} \cdot$ Michela Deiana $^{6,7} \cdot$ Stefano Romeo ${ }^{1,8}$.

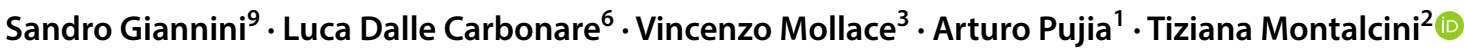

Received: 18 May 2020 / Accepted: 18 June 2020 / Published online: 30 June 2020

(c) Springer Science+Business Media, LLC, part of Springer Nature 2020

\begin{abstract}
C-peptide therapy protects against diabetic micro- and macrovascular damages and neuropatic complications. However, to date, the role of $\mathrm{C}$-peptide in preventing diabetes-related bone loss has not been investigated. Our aim was to evaluate if C-peptide infusion improves bone quality in diabetic rats. Twenty-three male Wistar rats were randomly divided into three groups: normal control group; sham diabetic control group; diabetic plus C-peptide group. Diabetes was induced by streptozotocin injection and C-peptide was delivered subcutaneously for 6 weeks. We performed micro-CT and histological testing to assess several trabecular microarchitectural parameters. At the end, diabetic plus C-peptide rats had a higher serum C-peptide $(p=0.02)$ and calcium $(p=0.04)$ levels and tibia weight $(p=0.02)$ than the diabetic control group. The diabetic plus C-peptide group showed a higher trabecular thickness and cross-sectional thickness than the diabetic control group ( $p=0.01$ and $p=0.03$ ). Both the normal control and diabetic plus C-peptide groups had more Runx-2 and PLIN1 positive cells in comparison with the diabetic control group $(p=0.045$ and $p=0.034)$. Diabetic rats receiving C-peptide had higher quality of trabecular bone than diabetic rats not receiving this treatment. If confirmed, C-peptide could have a role in improving bone quality in diabetes.
\end{abstract}

Keywords c-peptide $\cdot$ Bone microarchitectural parameters $\cdot$ Type 1 diabetes mellitus $\cdot$ Osteoporosis $\cdot$ Diabetic rat model

\section{Introduction}

It is widely accepted that type 1 diabetes mellitus (T1DM) can affect bone health and increase the risk of fractures [1]. A decreased bone mass has been reported for prepubertal and pubertal patients with T1DM [2] and bone loss has been found in over $50 \%$ of patients with juvenile-onset diabetes $[3,4]$. It has been suggested that adverse effects on bone health may occur earlier after a diabetes diagnosis

Samantha Maurotti and Cristina Russo have contributed equally to this work.

Electronic supplementary material The online version of this article (https://doi.org/10.1007/s00223-020-00716-0) contains supplementary material, which is available to authorized users.

Tiziana Montalcini

tmontalcini@unicz.it

Extended author information available on the last page of the article than subclinical cardiovascular adverse effects [5-7]. Of note, bone loss develops even in individuals under insulin therapy [8]. The risk of hip fractures in patients with T1DM is reported to be 7-12 times greater than individuals without diabetes $[1,9]$, which is much higher compared to the modest reduction in bone mineral density (BMD) seen in these patients [10]. This is because, in diabetic patients, microarchitectural changes are not fully reflected in the measurement of BMD [10].

Diabetes could affect bone through several mechanisms. Patients with T1DM fail to achieve peak bone mass (that is the maximum strength and density reached by a bone), in part due to lower insulin and IGF-1 levels [11]. In addition, concomitant diseases in individual with T1DM may cause bone loss [12]. Furthermore, the development of osteoporosis is imputable to the coexistence of chronic microvascular complications, which also affect the bone marrow blood vessels [13]. However, other mechanisms might be involved. It has been demonstrated that $\mathrm{C}$-peptide administration in 
T1DM patients results in amelioration of diabetes-induced renal and nerve dysfunction [14]. C-peptide is the 31-amino acid segment of the proinsulin hormone, which is secreted with insulin in equimolar amounts from the pancreatic $\beta$-cells and. T1DM is characterized by a C-peptide deficiency, due to the beta cell destruction $[15,16]$.

The beneficial effects of C-peptide on impaired nerve function induced by T1DM have been confirmed in several clinical studies [14, 17, 18]. Indeed C-peptide has been shown to protect against diabetic micro- and macrovascular damages [19, 20]. Therefore, C-peptide deficiency may be involved, at least in part, in the development of other pathological features associated with T1DM such as bone loss. However, to date, the effects of C-peptide replacement therapy on bone in T1DM has not been investigated either in in vivo or clinical studies.

At this time, no randomized clinical trials have directly evaluated the anti-fracture efficacy of the current osteoporosis treatments in diabetic patients. The management of these patients is, thus, largely empirical. Recently, two crosssectional studies suggested a pathogenic role of C-peptide deficiency in T1DM-related osteoporosis [21, 22] and one in vitro study demonstrated that C-peptide might modulate the synthesis of key proteins for bone metabolism in human osteoblast-like cells [23].

In this study, our aim was to assess the effects of a 6-week [24] continuous administration of rat C-peptide on bone in STZ-induced diabetic rats. Our hypothesis is that C-peptide would improve bone microarchitecture in T1DM. Thus, in this study we used micro-computed tomography (microCT) imaging, which allow characterization of bone microarchitecture.

Furthermore, since several proteins [25-28] are expressed in areas where bone is newly synthesized, in this study we investigated whether C-peptide therapy can influence the expression of some specific proteins involved in bone metabolism.

\section{Materials and Methods}

\section{Animals}

Twenty-three, four-month-old male Wistar rats (Charles River Laboratories) (400-500 g) were used. The rats were fed with a commercial standard diet containing $1 \%$ calcium, $0.7 \%$ phosphorus (of which $0.4 \%$ nonphytate phosphorus), $\mathrm{Ca} / \mathrm{P} 3: 1$ and $150 \mathrm{IU}$ of vitamin D3 per $100 \mathrm{~g}$. All rats were individually housed in polycarbonate cages and were kept under the same conditions. The environmental conditions were maintained constant with $12 \mathrm{~h} / 12 \mathrm{~h}$ light/day cycle, $24 \pm 1{ }^{\circ} \mathrm{C}$ temperature and $55 \pm 10 \%$ humidity. The animals had ad libitum access to pellets of standard rodent diet, as well as bottles of tap water.

\section{Experimental Design}

The rats were randomly divided into the following three groups:

Normal control group (no treatment; sacrificed at the end of the experiment)- CTR;

Diabetic control group (no treatment; sacrificed at the end of the experiment)-D-CTR;

Diabetic plus C-peptide group (C-peptide-treated; sacrificed at the end of the experiment)- C-PEP;

After a 2-week acclimation period, diabetes was induced by a single intraperitoneal injection of STZ $(60 \mathrm{mg} / \mathrm{kg}$ body weight) (Fig. 1). In all the animals, blood glucose and C-peptide level were measured before STZ injection (baseline assessment by laboratory tests, 14 days after the arrival), then STZ was dissolved in ice-cold citrate buffer $(0.05 \mathrm{M}$ citric acid, $\mathrm{pH}$ 5.1) and injected immediately within few minutes to avoid degradation.

Blood glucose level was measured daily following the initial administration of STZ using a glucometer method (Accutrend ${ }^{\circledR}$ alpha-Boehringer Mannheim). Despite the day after glucose concentration was more than $300 \mathrm{mg} / \mathrm{dl}$, animals were considered diabetic only if their blood glucose levels were $>300 \mathrm{mg} / \mathrm{dl}(16.6 \mathrm{mmol} / \mathrm{L})$ two weeks after STZ injection (see experimental study design, Fig. 1).

To prevent ketosis, a moderate dose of rapid and intermediate insulin was administered (Humalog and Humulin I, Eli Lilly Italia S.p.A.) when blood sugar levels were higher than $400 \mathrm{mg} / \mathrm{dl}$ in order to maintain a glucose level below $350 \mathrm{mg} / \mathrm{dl}$.

Serum C-peptide level was also measured 2 weeks after STZ injection (on day 28, at treatment start, Fig. 1) as well as at the study end (on day 70).

Furthermore, other laboratory assessments were conducted throughout the study, precisely serum creatinine, calcium, phosphorus and CTX-I were assessed before STZ injection, 14 days after the arrival (baseline assessment) as well as at study end (Fig. 1) while RANKL and blood count only once, at the study end (day 70).

On day 28 ( 2 weeks after STZ injection), the rat C-peptide (>95\% purity, RP-HPLC) was delivered in C-PEP group, via subcutaneously implanted osmopumps (Alzet 2006, Alza, Palo Alto, CA) delivering $72 \mathrm{nmol} \cdot \mathrm{kg}^{-1} \cdot 24 \mathrm{~h}^{-1}$ [29] for 6 weeks [24], while the D-CTR group was sham-operated (Fig. 1). Rat C-peptide was provided by Dr John Wahren, Karolinska Institutet, Stockholm, Sweden.

During the course of this study, animals were weighed weekly and nonfasting blood glucose levels were recorded every day. The animals were euthanized after 6 weeks (bone depletion period) [27] by isoflurane inhalation. 


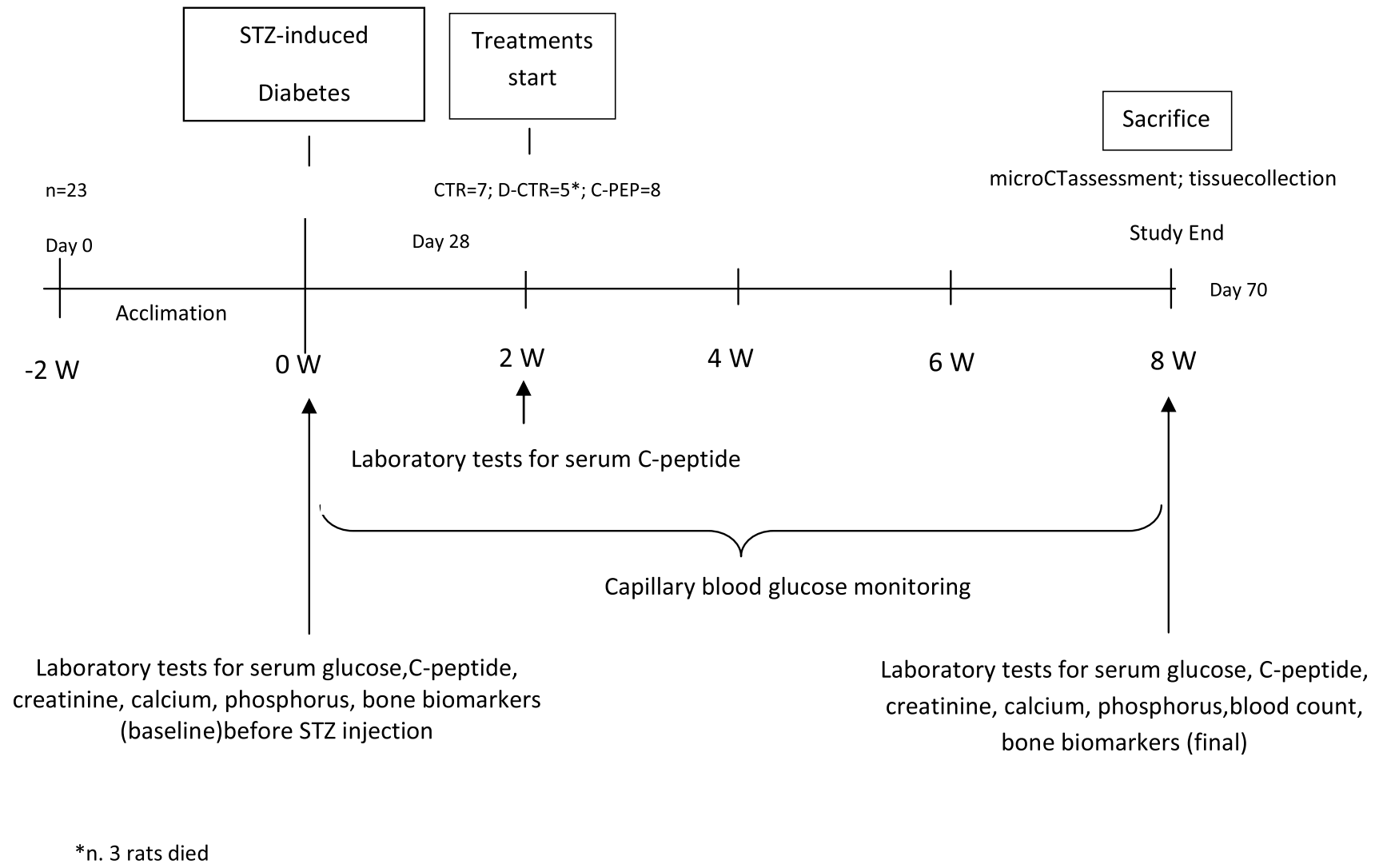

Fig. 1 Experimental design of the study

This work was conducted according to the European guidelines (2010/63/EU) for reducing animal suffering. In particular, the animals were anesthetized before STZ administration, osmopump implantation and venous blood collection by isoflurane inhalation. The health-conditions of the animals were monitorized daily. After the induction of diabetes, a total of three animals near death were immediately euthanize.

The study design is outlined in Fig. 1.

\section{Tissue Collection}

Femurs and tibiae were obtained postmortem, dissected and cleaned of adherent soft tissues.

The right femurs were immediately scanned using micro-computed tomography (micro-CT) as described below. The left femurs were fixed by immersion in formalin and stored for histologic assessments. The left tibiae from each animal were stored in plastic vials at $-70{ }^{\circ} \mathrm{C}$ for ashing to assess calcium content.

\section{Parameters of General Health and Bone Metabolism}

Venous blood was collected after 2 weeks of acclimation (baseline assessment before STZ injection), 2 weeks after STZ injection, (before treatment start) and at end of the study (Fig. 1). All serum samples were stored frozen at $-20{ }^{\circ} \mathrm{C}$ until assayed.

Specifically, serum glucose, calcium and phosphate concentration were analysed by Roche Module COBAS 8000 (Roche Diagnostics, Indianapolis, IN).

Serum C-peptide was assessed with an enzymatic colorimetric test by ELISA kit (Crystal chem, Inc. USA). Both the CTX and RANKL were measured by ELISA kits (Cusabio Biotech Co, USA) but RANKL was measured only at the end of the study.

The haematological parameters, which were assessed at the end of the study (only once), were analysed by using an automated hematological analyser (ADVIA Siemens Healthcare Diagnostic Inc.; Germany). All measurements were performed in duplicate. 


\section{Micro-Computed Tomography}

We scanned the samples using Skyscan 1176 micro-CT system (Bruker microCT, Skyscan, Belgium). In order to avoid drying of the samples, we wrapped the femur of each animal with a thin layer paper soaked in saline solution and then analysed along the longitudinal axis of the specimen.

We analysed the distal femur's portion [30], under the following scanning conditions and parameters: $65 \mathrm{kV}, 380 \mu \mathrm{A}$, $25 \mathrm{~W}, 950 \mathrm{~ms}$ exposure time, $1 \mathrm{~mm}$ aluminium filter, $1 \times 1$ camera binning and $9 \mu \mathrm{m}$ isotropic resolution, rotation step of $0.3^{\circ}, 12.47$ um camera pixel size.

The reconstruction of the projection images was performed in NRecon software (Bruker microCT, Belgium) on InstaRecon platform (InstaRecon, USA) with appropriate thermal drift correction, misalignment compensation, Gaussian smoothing of 1, and appropriate ring artifact and beam hardening corrections. Ct.An program version 1.15.4 (Skyscan, Belgium) was used for quantitative analysis of the data. The volume of interest (VOI) was identified as follow: in each femur the reference slice corresponding to the upper end of the distal femur's growth plate cartilage was identified, according to the manufacturer's recommendation, and trabecular VOI comprised the slices from number 100-500 proximal to the reference slice. Hand-drawn contours were used to isolate the metaphyseal region of interest and trabecular compartments based on 400 consecutive slices [31]. Threshold was set automatically through Ct.An software (Otsu automatic threshold); subsequently, the suggested values were checked manually by simultaneous overview of raw and thresholded images, which allowed us to fine-tune the threshold level to best represent the mineralized bone tissue. All the procedures were standardized and the same threshold was applied for all specimens to allow inter-individual comparisons of microarchitectural parameters [30]. Trabecular parameters were as follows: Trabecular volumetric bone mineral density [vBMD; mg hydroxyapatite $(\mathrm{HA}) / \mathrm{cm}^{3}$ ], bone volume fraction (BV/TV; \%), trabecular thickness (Tb.Th; mm), trabecular number (Tb.N; $1 / \mathrm{mm}$ ), trabecular separation (Tb.Sp; mm), structure model index (SMI), connectivity density (Conn.D; $1 / \mathrm{mm}^{3}$ ) and crosssectional thickness (Cs.Th; mm).

The parameters of bone geometry were also assessed: bone perimeter (B.Pm, mm) that represents total perimeter of the diaphyseal bone cross-section, and tissue perimeter (T.pm; mm).

\section{Histomorphometry}

The study of microarchitecture was based on the measure of width, number, and separation of trabeculae as well as on their spatial organization.
The samples were fixed in 70\% ethanol and embedded undecalcified in methyl-methacrylate resin. Bone sections were cut by using a microtome (Pfm Rotary 3000 BioOptica, Germany) equipped with a carbide-tungsten blade, stained with Goldner's stain and mounted on microscope slides for histomorphometric measurements. Measurements were taken by means of an image analysis system consisting of an epifluorescent microscope (Leica DM2500) connected to a digital camera (Leica DFC420 C) and a computer equipped with a specific software for histomorphometric analyses (Bone 3.5, Explora Nova, France). We evaluated parameters of structure such as bone volume/tissue volume ( BV/TV; \%), trabecular thickness (Tb.Th; mm), trabecular number (Tb.N; N/mm), trabecular separation (Tb.Sp; mm); and of microarchitecture such as marrow star volume (MSV, $\mathrm{N} / \mathrm{mm}^{3}$ ), trabecular bone pattern factor (TBPf) and fractal dimension (FD) as previously described [32]. Histomorphometric parameters were reported in accordance with the ASBMR Committee nomenclature [33].

\section{Immunohistochemistry}

In order to identify the proteins in tissue sections (cellular and matrix components of bone), samples from femur middiaphysis embedded in paraffin underwent immunohistochemistry (IHC) analyses by incubating the samples with antibodies specific to the protein of interest, and then visualizing the bound antibody using a chromogen [34].

Osteoblast differentiation in decalcified bone sections of the rats was investigated in transverse Sects. $(5 \mu \mathrm{m})$ from femur by incubating the samples with mouse anti-Runx-2 (an osteoblast marker) antibody (1:1000 dilution in PBS containing $0.5 \%$ BSA, Cell Signaling Technology) at $4{ }^{\circ} \mathrm{C}$. Sections were washed with PBS and signal was detected using the Ultravision ONE Detection System HRP polimer \& DAB Plus Chromogen (Thermo Scientific) with Runx-2 positive cells were counted in five randomly selected fields from six bone sections of each group and quantified with Image-Pro plus 6.1 software.

Since there could be an associations between proteins that regulate fat metabolism and skeletal mass, immunohistochemical staining for perilipin 1 (PLIN1, which coats the lipid droplets in adipocytes) [35] was performed incubating the samples with mouse anti-PLIN1 antibody (1:1000 dilution in PBS containing 0.5\% BSA, Cell Signaling Technology).

An immunohistochemical analysis was also conducted to investigate on the proteins eventually involved in tensile strength and bone healing by monoclonal antibodies against collagen I alpha 1 (COLIA1, 1:500, Santa Cruz biotechnology) and bone sialoprotein (BSP, 1:1000 dilution in PBS containing 0.5\% BSA, Cell Signaling Technology). 
We count the percentage of positive immunolabeled cells over the total cells in each selected area.

\section{Anthropometric and Compositional Analysis of the Tibia (Calcium Content)}

Left and right tibiae were dissected and weighed to $0.1 \mathrm{~g}$ accuracy on an electronic balance. A digital caliper accurate to $0.01 \mathrm{~mm}$ was used to measure the tibiae length in the sagittal plane. These measurements were taken three times and the average was calculated. We then calculated the mean between left and right tibiae.

The left tibiae were dried in a vacuum oven at $110{ }^{\circ} \mathrm{C}$ for $6 \mathrm{~h}$ and the dry mass was recorded. Then tibiae were ashed at $800{ }^{\circ} \mathrm{C}$ for $4 \mathrm{~h}$, weighed again and dissolved in $1 \mathrm{~mL} 6 \mathrm{~N} \mathrm{HCl}$. Calcium content $(\mathrm{mg} / \mathrm{dl})$ was obtaining by colorimetric determination with Quantichrom calcium Assay kit [36] (BioAssay Systems, Hayward, CA).

\section{Statistical Analysis}

The results are expressed as mean \pm S.D. Continuous data normalcy was analysed through the Shapiro-Wilk test and Box plot method. The outlier values that were considered due to measurement error or capture were excluded from the analysis. In the case of normal data, ANOVA test was used to compare the means between groups (specifically, anthropometric and laboratory parameters). In the case of nonnormal data (microarchitectural parameters and RANKL), the nonparametric Kruskal-Wallis followed by Mann-Whitney tests were used to evaluate the differences between groups. All the significant differences were adjusted for the baseline body weight (after acclimation period) by a General Linear Model (GLM) with Bonferroni correction as post hoc analysis. Changes from baseline to the end of the study (within group variation in body weight, glucose, electrolytes and C-peptide) were assessed using a paired Student's $t$ test (two tailed).

We categorized the immunohistochemistry scores (of PLIN1, RUNX, BSPI and COL1A) according to three groups of values (group I, score $<3$; group II, score equal to 3; group III, score $>3$ ) and a Chi-squared test was used for comparisons of these categorical variables.

Pearson and Spearman's correlation was performed for normal and nonnormal data, respectively, to assess the statistical dependence between variables. A probability value of less than 0.05 was considered statistically significant. All statistical analyses were performed using SPSS for Windows, version 22.0 (IBM Corporation, New York, NY, United States).

\section{Results}

Rats in the D-CTR and C-PEP groups were injected with the same dose of insulin (Table 1).

\section{General Health}

At baseline, the groups were comparable for all of the characteristics (Table 1), except for body weight.

The CTR group body weight was significantly lower than D-CTR and C-PEP body weights $(p<0.005$ and $p<0.030$, respectively, Table 1 ). The CTR rats gained weight during the experimental period of 42 days, whereas the D-CTR rats had 11\% and the C-PEP group had 7\% decreases in the final body weight, compared to the initial weight (Table 1, Supplementary Fig. 1).

STZ injection resulted in a significant reduction of serum C-peptide in both the sham D-CTR and the C-PEP group relative to the CTR group, at the end of the treatment phase (Fig. 2). The D-CTR rats had $79 \%$ and the C-PEP group had $41 \%$ decreases in the final serum C-peptide compared to the initial C-peptide level (Fig. 2).

At the end of the study, C-peptide level did not differ between CTR and C-PEP groups ( $p=0.09$; Table 1; Fig. 2d).

Serum C-peptide was higher in the CTR than the D-CTR group $(p=0.02)$. Furthermore, C-peptide was higher in the C-PEP than D-CTR group ( $p=0.05$, Table 1$)$.

Supplemental Fig. 3 shows the time course of glucose and C-peptide during the study.

At the end of the study, the C-PEP group had a lower serum glucose level than the D-CTR group $(194 \pm 28$ vs $404 \pm 33, p=0.001$ ).

Moreover, at the end of the study, the C-PEP group had a higher serum phosphorus level than the CTR $(p=0.02)$ and the D-CTR $(p=0.05)$ groups as well as a higher calcium levels than the D-CTR ( $p=0.04$, Fig. 2c). C-peptide infusion prevented the reduction of red cells and haemoglobin seen in the D-CTR group (for red cells, D-CTR vs C-PEP, $\mathrm{p}<0.004$; for haemoglobin, D-CTR vs C-PEP, $p<0.005$; Table 2).

\section{Anthropometric and Compositional Analysis of the Tibia}

At the end of the study, the CTR group exhibited a higher mean tibia weight than the D-CTR group (CTR vs D-CTR, $p=0.05$, Table 2). Calcium content and ash weight did not differ between these two groups (Table 2).

C-PEP group exhibited a higher tibia weight than the D-CTR group (C-PEP vs D-CTR, $p=0.02$, Table 2). 


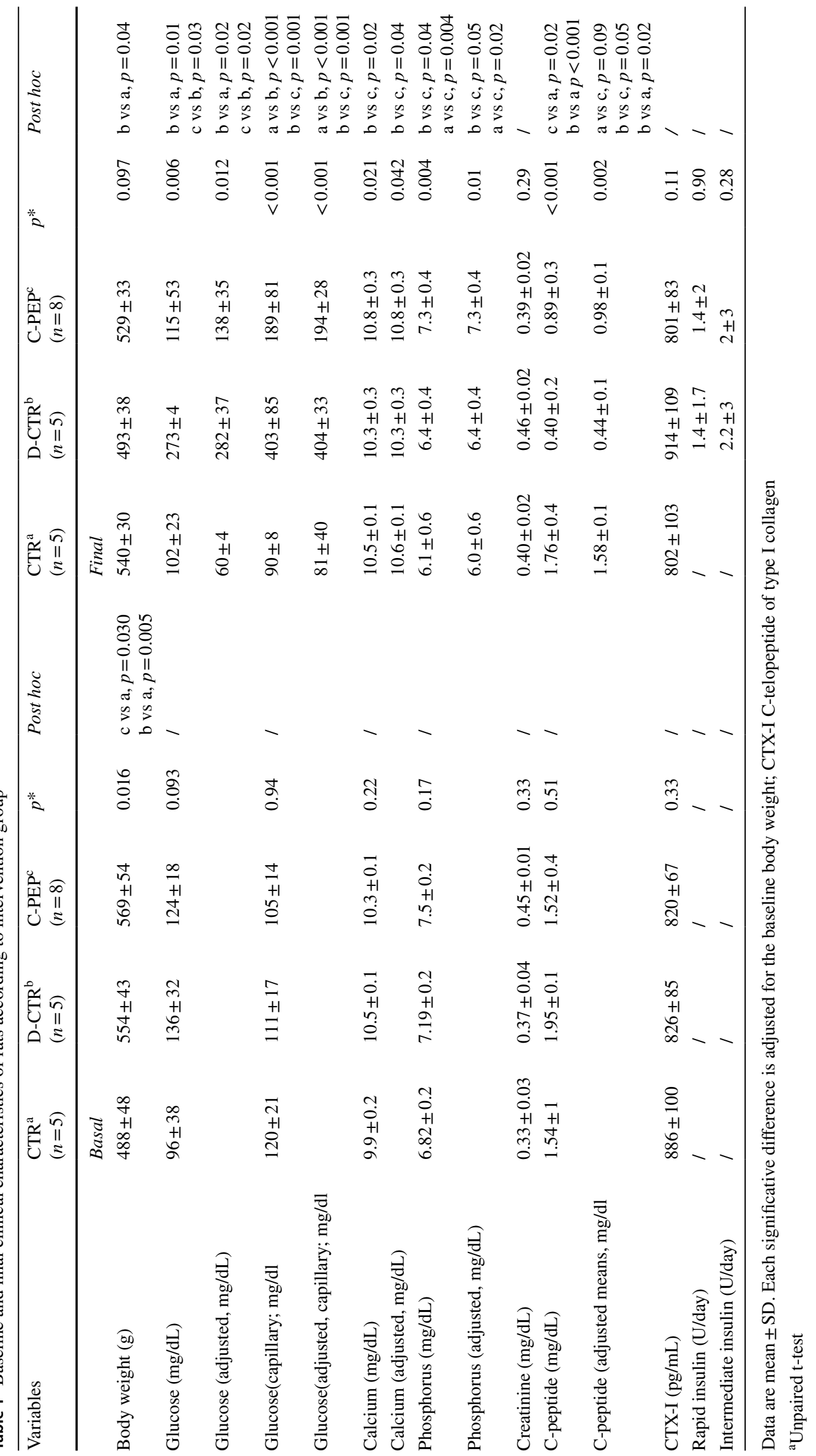



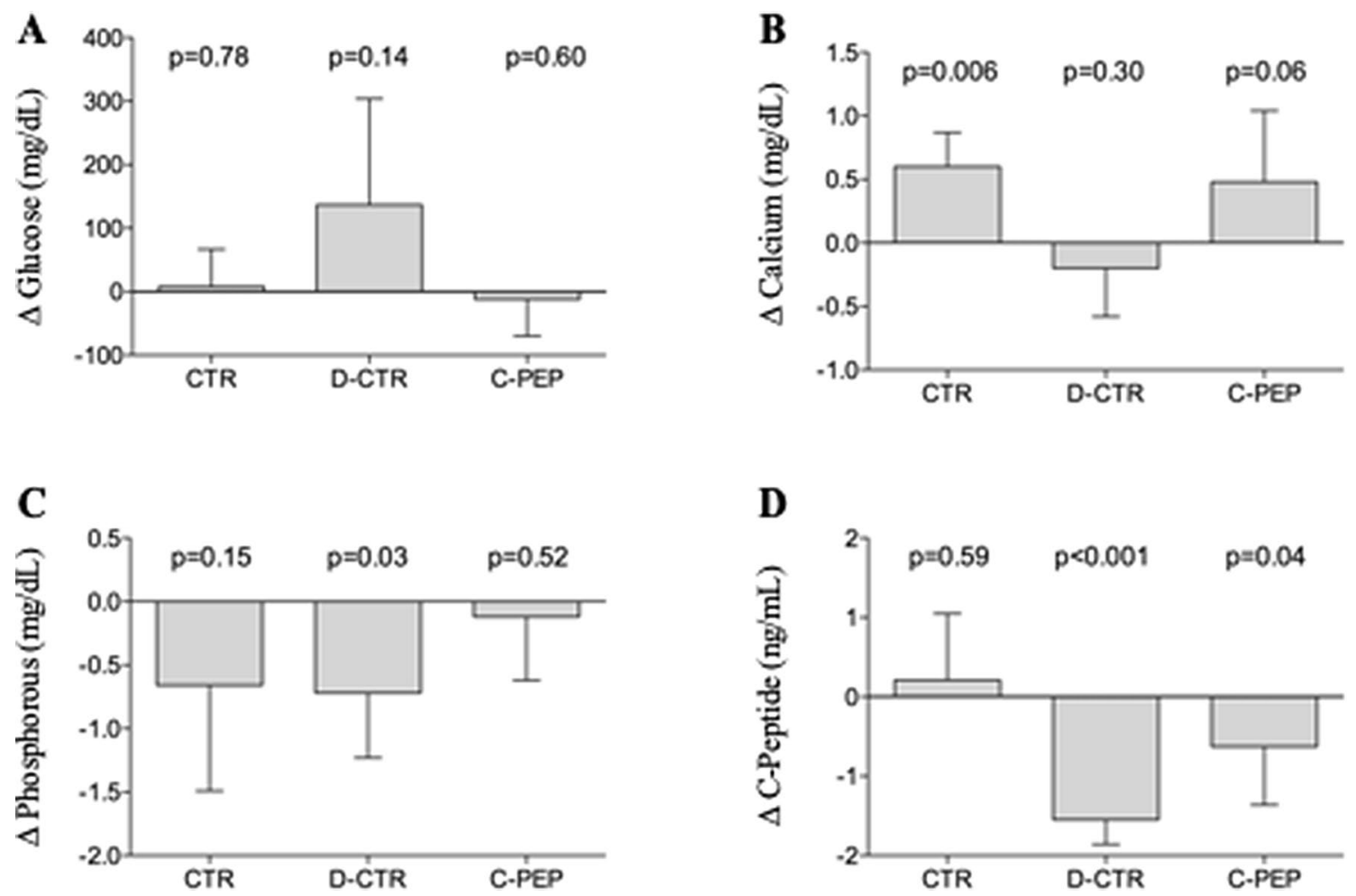

Fig. 2 Change in laboratory parameters from baseline according to intervention groups of serum a glucose $\mathbf{b}$ calcium $\mathbf{c}$ phosphorus and $\mathbf{d}$ C-Peptide

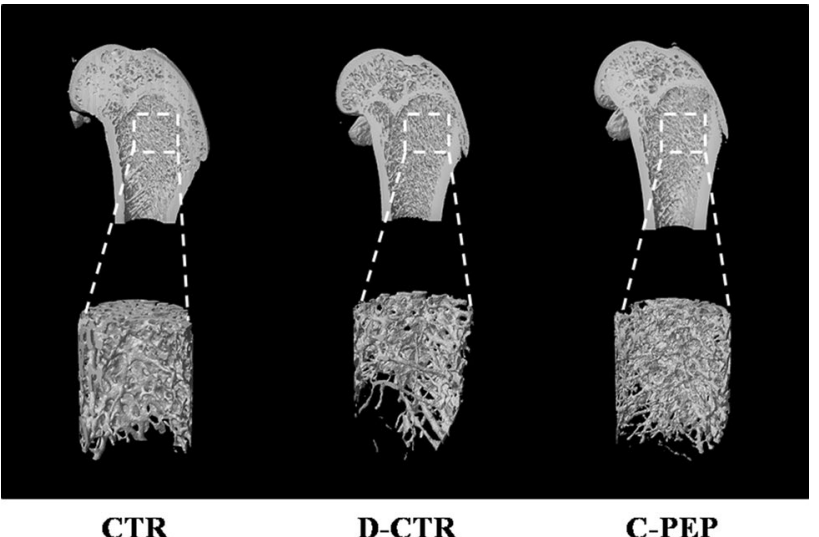

CTR

Fig. 3 Three-dimensional images of femur epiphysis among groups

Calcium content did not differ between these groups. C-PEP group had a higher ash weight than D-CTR as well as CTR groups ( $p=0.022$ and $p=0.01$ respectively; Table 2) but this difference did not remain after adjustment $(p=0.08)$.

\section{Correlation Between Serum C-Peptide, RANKL and Microarchitecture Parameters}

C-peptide significantly and positively correlated with Cs.Th $\left(r=0.63, p=0.01, r^{2}=0.39\right)$ (Table 3 and Supplemental Fig. 3). Furthermore, Table 3 shows a positive correlation between one of the IHC assessments (i.e. the PLIN1 score) and serum C-peptide ( $r=0.48, p=0.04, r^{2}=0.17$, Table 3$)$. Table 3 also reported the correlation between the final serum RANKL and several radiological parameters of bone microarchitecture. RANKL positively correlated with the vBMD $\left(r=0.50, p=0.03, r^{2}=0.32\right.$, Supplementary Fig. 3).

\section{Micro-CT Assessments}

Three-dimensional images of femur epiphysis showed differences in trabecular microarchitecture among the various groups as represented in Fig. 3. Analysis of the representative samples data indicates that C-peptide replacement therapy prevented the trabecular osteopenia. Micro-CT evaluation of the femoral trabecular bone showed inter-group differences in Tb.Th, Cs.Th and Tb.Sp ( $p=0.02 ; p=0.05$ and $p=0.05$ respectively, Table 4 ).

No trabecular microarchitecture parameters differed between CTR and C-PEP groups (Table 4, post hoc analysis). 
Table 2 Clinical characteristics of rats assessed at the end of the study (only once), according to intervention group
Table 3 Bivariate correlations between serum C-peptide and several clinical, radiologic and histological parameters in rats

\begin{tabular}{|c|c|c|c|c|c|}
\hline Variables & $\begin{array}{l}\mathrm{CTR}^{\mathrm{a}} \\
(n=5)\end{array}$ & $\begin{array}{l}\text { D-CTR }{ }^{\mathrm{b}} \\
(n=5)\end{array}$ & $\begin{array}{l}\text { C-PEP } \\
(n=8)\end{array}$ & $p$ value & $\begin{array}{l}p \text { value } \\
\text { post hoc }\end{array}$ \\
\hline Femur weight $(\mathrm{g})^{\mathrm{a}}$ & $1.46 \pm 0.07$ & $1.54 \pm 0.17$ & $1.55 \pm 0.09$ & 0.41 & l \\
\hline Femur length $(\mathrm{cm})^{\mathrm{a}}$ & $4.5 \pm 0.2$ & $4.8 \pm 0.1$ & $4.5 \pm 0.1$ & 0.49 & l \\
\hline Tibia weight $(\mathrm{g})^{\mathrm{a}}$ & $1.09 \pm 0.1$ & $1.08 \pm 0.2$ & $1.2 \pm 0.1$ & 0.08 & \\
\hline Tibia weight (adjusted, $\mathrm{g})^{\mathrm{a}}$ & $1.2 \pm 0.08$ & $1.06 \pm 0.05$ & $1.2 \pm 0.05$ & 0.09 & $\begin{array}{l}\text { c vs b, } p=0.02 \\
\text { a vs b, } p=0.05\end{array}$ \\
\hline Tibia length $(\mathrm{g})^{\mathrm{a}}$ & $5 \pm 0.2$ & $5.3 \pm 0.1$ & $5.2 \pm 0.1$ & 0.69 & l \\
\hline Tibia calcium content $(\mathrm{g} / \mathrm{dL})$ & $5.8 \pm 6$ & $3.18 \pm 5$ & $5.7 \pm 6$ & 0.75 & l \\
\hline Ash weight (g) & $0.38 \pm 0.03$ & $0.39 \pm 0.05$ & $0.45 \pm 0.03$ & 0.022 & $\begin{array}{l}\text { a vs c, } p=0.016 \\
\text { b vs c, } p=0.02\end{array}$ \\
\hline Ash weight (adjusted, g) & $0.41 \pm 0.02$ & $0.38 \pm 0.01$ & $0.43 \pm 0.01$ & 0.08 & \\
\hline $\mathrm{RBC}\left(10^{6} / \mu \mathrm{L}\right)$ & $9.1 \pm 0.2$ & $8.6 \pm 0.7$ & $9.8 \pm 0.7$ & 0.01 & $\mathrm{~b}$ vs c, $p=0.004$ \\
\hline Hemoglobin $(\mathrm{g} / \mathrm{dL})$ & $15.5 \pm 0.3$ & $13.8 \pm 1$ & $16.1 \pm 1$ & 0.019 & $\mathrm{~b}$ vs c, $p=0.006$ \\
\hline $\mathrm{WBC}\left(10^{3} / \mu \mathrm{L}\right)$ & $6.5 \pm 3$ & $11.4 \pm 3$ & $11.8 \pm 0.3$ & 0.131 & I \\
\hline
\end{tabular}

Data are mean $\pm \mathrm{SD}$

$R B C$ red blood cell; $W B C$ white blood cell

${ }^{a}$ Mean value between left and right; each significative difference is adjusted for the baseline body weight

\begin{tabular}{lllllll}
\hline Variables & & Cs.Th $^{\mathrm{a}}$ & PLIN1 $^{\mathrm{c}}$ & Body weight & & \\
\hline Final C-peptide $(\mathrm{ng} / \mathrm{mL})$ & $r$ & 0.63 & 0.48 & -0.55 & & \\
& $p$ & 0.011 & 0.04 & 0.017 & & \\
& & T.Pm & Conn.Dn & & \\
& & Tb.N $^{\mathrm{b}}$ & Tb.Sp $^{\mathrm{b}}$ & MSV $^{\mathrm{b}}$ \\
Tb.Th $(\mu \mathrm{m})$ & & 0.58 & 0.59 & -0.84 & 0.78 & 0.61 \\
& $p$ & 0.02 & 0.03 & $<0.001$ & 0.001 & 0.02 \\
& & $\mathrm{BMD}^{*}$ & B.Pm* & T.Pm* & Tb.Sp* & Body weight \\
RANKL $(\mathrm{pg} / \mathrm{mL})$ & $r$ & 0.50 & 0.57 & 0.60 & -0.61 & 0.49 \\
& $p$ & 0.03 & 0.01 & 0.009 & 0.02 & 0.03 \\
\hline
\end{tabular}

Rank- $L$ receptor activator of nuclear factor kappa-B ligand; BMD bone mineral density; B.Pm mean total cross-sectional bone perimeter; T.Pm mean total cross-sectional tissue perimeter; Tb.Sp trabecular separation; Tb.N trabecular number; Cs.Th cross-sectional thickness; Conn.Dn connectivity density; PLIN1 perilipin 1; NEUT neutrophils; MSV marrow star volume

${ }^{\text {a }}$ Radiologic parameters

${ }^{\mathrm{b}}$ Histomorphometric parameters

${ }^{\mathrm{c}}$ Score groups

The D-CRT group showed a lower Tb.Th and Cs.Th than the C-PEP group (-13\%), also after adjustment $(p=0.01$ and $p=0.03$, respectively; Table 4 ).

The C-PEP group showed lower Tb.Sp than the other groups $(p=0.05)$ but the significant difference was lost after adjustment.

Data regarding Conn.D, SMI, B.Pm, T.Pm are showed in Supplemental Table 1. These parameters did not differ between groups.

\section{Histomorphometric Parameters}

After the treatment phase, neither of these parameters showed significant differences between groups. There was a significant correlation between the $\mathrm{Tb}$. Th, assessed histologically, and two radiologic parameters (such as T.pm and Conn.D, see Table 3).

\section{Immunohistochemistry Parameters}

Both the CTR and C-PEP groups had more Runx-2 and PLIN1 positive cells (with a score of over 2) in comparison with the D-CTR group ( $p=0.045$ and $p=0.034$, respectively, Fig. 4).

\section{RANKL Among Groups}

There was a significant difference in RANKL, by Mann-Whitney test, between groups (CTR vs C-PEP $p=0.01$ and D-CTR vs C-PEP $p=0.02$, Table 4). After 
Table 4 Results of the nonparametric Kruskal-Wallis test for comparison among treatment groups of the radiologic parameters of microarchitecture and RANKL, as represented by the average and the

\begin{tabular}{|c|c|c|c|c|c|c|c|c|c|}
\hline \multirow[t]{2}{*}{ Variables } & \multirow{2}{*}{$\begin{array}{l}\mathrm{CTR}^{\mathrm{a}} \\
(n=5)\end{array}$} & \multirow{2}{*}{$\begin{array}{l}\text { D-CTR } \\
(n=5)\end{array}$} & \multirow{2}{*}{$\begin{array}{l}\text { C-PEP } \\
(n=8)\end{array}$} & \multirow{2}{*}{$\begin{array}{l}p \text { value } \\
\text { (Kruskal- } \\
\text { Wallis } \\
\text { test) }\end{array}$} & \multirow{2}{*}{$\begin{array}{l}p \text { value } \\
\text { (Mann-Whitney) }\end{array}$} & \multirow{2}{*}{$\begin{array}{l}p \text { value } \\
\text { Adjusted* }\end{array}$} & \multirow[t]{2}{*}{ Post hoc } & \multicolumn{2}{|l|}{ CI $95 \%$} \\
\hline & & & & & & & & Lower & Higher \\
\hline Tb.Sp (mm) & $0.76 \pm 0.1$ & $0.64 \pm 0.1$ & $0.53 \pm 0.01$ & 0.05 & a vs $\mathrm{c}, p=0.016$ & 0.26 & I & & \\
\hline CS.Th (mm) & $0.081 \pm 0.01$ & $0.070 \pm 0.01$ & $0.079 \pm 0.005$ & 0.05 & $\begin{array}{l}\text { a vs b, } p=0.03 \\
\text { b vs c, } p=0.04\end{array}$ & 0.032 & $\mathrm{~b}$ vs c, $p=0.03$ & -0.001 & -0.017 \\
\hline Tb.Th (mm) & $0.122 \pm 0.001$ & $0.111 \pm 0.001$ & $0.125 \pm 0.007$ & 0.02 & $\begin{array}{l}\text { a vs b, } p=0.03 \\
\text { b vs c, } p=0.01\end{array}$ & 0.012 & $\mathrm{~b}$ vs $\mathrm{c}, p=0.01$ & -6.1 & -0.01 \\
\hline RANKL (pg/mL) & $63 \pm 65$ & $94 \pm 46$ & $237 \pm 112$ & 0.01 & $\begin{array}{l}\text { a vs c, } p=0.01 \\
\text { b vs c, } p=0.02\end{array}$ & 0.041 & b vs c, $p=0.04$ & -0.409 & -264 \\
\hline
\end{tabular}

Data are mean $\pm \mathrm{SD}$

Tb.Sp trabecular separation; Cs.Th cross-sectional thickness; Tb.Th trabecular thickness; RANKL receptor activator of nuclear factor kappa-B ligand. *For baseline body weight with Bonferroni multiple comparisons

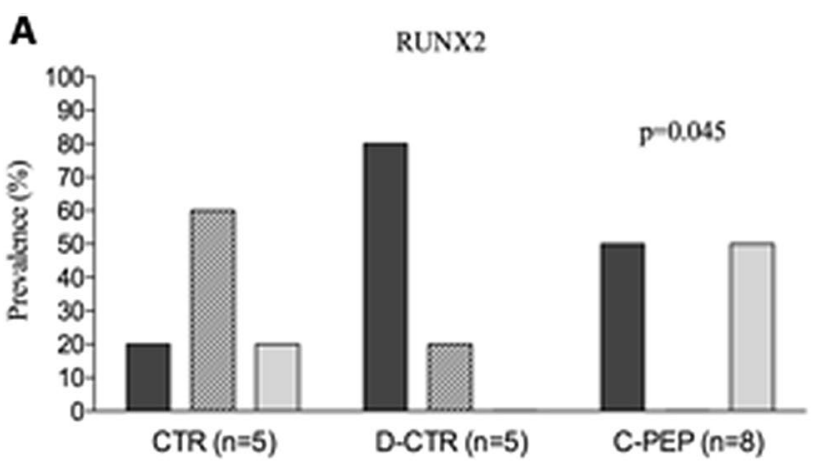

口group score I Egroup score II $\square$ group score III

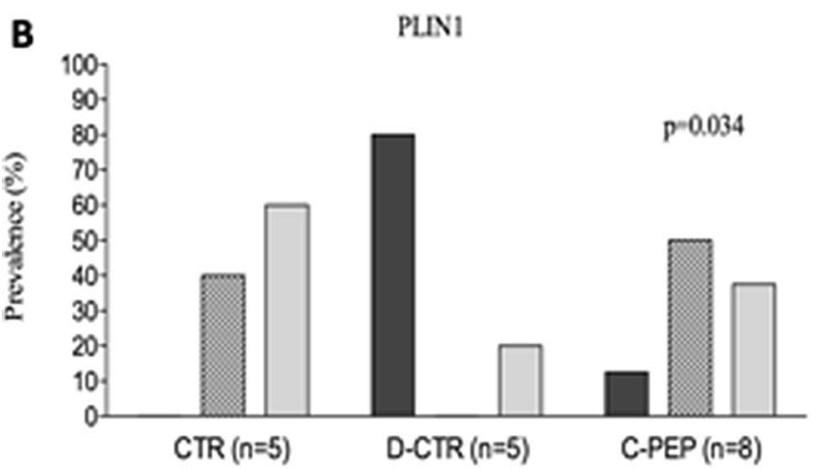

口group score I 탱group score II $\square$ group score III

Fig. 4 Scores of the Immunohistochemistry parameters across groups

adjustment, C-PEP had a higher serum RANKL than D-CRT (D-CRT vs C-PEP, $p=0.04$, Table 4). standard deviation values, and the significance level $(p)$ of the variation, with also correction test 
which included a minimal set of variables to describe the effects of C-peptide on trabecular bone structure and, consequently, bone strength. Because patients with osteoporosis commonly sustain a fracture of the femur, in the present study we choose this anatomical region for all the trabecular assessments.

In our study, a significant difference in radiological and histological data was found between the groups.

D-CTR rats had a $13 \%$ lower Tb.Th as well as Cs.Th over 6 weeks compared to C-PEP group. After only two months of diabetes, the femur of the D-CTR group lost $9 \%$ of Tb.Th and $14 \%$ of Cs.Th compared to CTR rats, while the C-PEP rats gained $2.5 \%$ of Tb.Th and lost only $2 \%$ of Cs. Th (Table 4).

It is well accepted that the ovariectomized rat is considered the gold standard model of postmenopausal bone loss in humans. It has been reported a Tb.Th of $0.10 \mathrm{~mm}$ in ovariectomized rats fed with a low calcium diet, three months after surgery, while a value of $0.13 \mathrm{~mm}$ in control rats [37]. In addition, a study conducted in mice reported, three months after induction of diabetes, a Tb.Th of $0.08 \mathrm{~mm}$ in diabetic rats and $0.12 \mathrm{~mm}$ in normal mice, at femoral neck [38]. The magnitude of the Tb.Th difference between the D-CTR and C-PEP rats (of $\sim 0.015 \mathrm{~mm}$ ) (Table 4), was the same as that observed in another study [39].

Animals in the C-PEP group also had a lower Tb.Sp than those in the D-CTR group (Table 4). All these parameters are key measures in characterizing the three-dimensional structure of cancellous bone and correlate to bone strength [40]. Effective treatments may increase the trabecular bone by thickening the trabeculae. We hypothesize that C-peptide therapy led to the deposition of the new bone matrix in layers around the trabeculae, which thus became thick at the expense of the spaces between them.

Both the increase in Tb.Th and Cs.Th means that C-peptide might improve bone quantity, leading to a better quality. All the bone microarchitecture parameters are reasonable surrogates for, and a predictor of, architecture and strength [41]. The mechanical significance of these parameters is not obvious; however, a difference exists between these parameters.

It is well accepted that thinner trabeculae make the bone structure more vulnerable to external loading and jeopardize the mechanical stability of trabecular bone. Thus, thickened trabeculae (high Tb.Th) offer the most mechanically sound solution to resist to loads and suggest that the spatial distribution of bone is arranged to resist greater loading [42]. As consequence, the spacing between trabeculae appears to be small (Tb.Sp; Table 4). On the contrary, the geometric property that best defines resistance to bending and torsional stresses would be the section modulus (crosssectional geometry) [31]. An increased Cs.Th means, in terms of mechanical properties, that trabecular bone is relatively strong due to new bone formation (or suppress bone resorption).

It is possible that the effects of C-peptide may also be exerted via blood glucose control, or by improving the response to insulin action. In fact, in line with previous reports of an increased whole body glucose utilization [43, 44] and glucose transport in skeletal muscle [45], in our study, C-peptide treatment prevented the hyperglycaemia seen in D-CTR (Table 1, Supplementary Fig. 2). We found discordant values between capillary and laboratory assessments (Table 1). However, C-PEP rats had a better glucose control than D-CTR rats. Additional studies are needed in order to elucidate the role of C-peptide on glucose homeostasis, which in turn, may lead to the improvement of bone microarchitecture parameters.

It has been reported that durations of T1DM exceeding 8 and 14 weeks are required before significant differences in material strength and toughness between diabetic and control rodents, respectively, are typically observed [46]. Thus, with a longer study duration and a higher dose of C-peptide than that infused, we would have achieved better results.

Moreover, we have chosen to study a lower number of animals than expected by the calculation of the sample size, to limit the suffering in animals, even if this has limited the study.

We found that both the CTR and C-PEP rats had, in femur sections, higher RUNX-2 proteins than the D-CTR group (Fig. 1a). This finding is in line with a study demonstrating that Runx2 expression, which mediates the bone-forming action of Irisin, in turn triggers a global osteogenesis gene program [47]. Once expressed, this transcription factor drives osteoblasts to synthesize and secrete bone extracellular matrix, including type I collagen, bone sialoprotein and osteocalcin [47]. These actions could explain, at least in part, our finding of a high tibia weight in both the CTR and C-PEP groups.

All these findings were parallel with the changes observed, during the study, in the levels of serum C-peptide (Table 1, Supplementary Fig. 1). At the end of the treatment period, serum C-peptide was higher in the C-PEP group than in the D-CTR group (Table 1) whereas it did not differ between the CTR and C-PEP groups. The dose of C-peptide we used was probably insufficient to normalize the serum C-peptide. We, therefore, assume that, with a higher dose than that infused, we would have achieved this normalization.

Of note, the effect of C-peptide therapy on bone parameters sometimes exceeded those seen in the CTR group without C-peptide, which further highlights the potential efficacy of C-peptide as a pharmacological agent.

In line with previous studies [48, 49], in the present investigation the D-CRT group exhibited similar microarchitectural parameter values to the CTR group (as Tb.Sp; Table 4). 
Again, it has been suggested that a significant bone loss occurs in STZ-induced diabetes after 12 weeks [50]. This could also explain the lack of difference in vBMD between the rat groups as well as the bone histological parameters. A longer observation time would however have led to better observations of both the radiological and histological changes in the trabecular bone in T1DM rats.

However, our findings are of clinical relevance. Although osteoporosis is related to an increased risk of fracture, most fractures occur in those with osteopenia [51]. Similarly, fragility fractures can occur in individuals with normal BMD [52]. Bone microstructural deterioration increases bone fragility exponentially, disproportionate to the modest deficits in BMD found in postmenopausal women with osteopenia [53-55]. The various parameters representing the trabecular bone compartment are associated with estimated bone strength and fragility fractures, also in individuals with diabetes $[56,57]$. Thus, our results may serve to design future studies to identify new therapies for neglected phenotypes of osteoporosis as in diabetes.

In our study, in histological samples from the femur of both C-PEP and CTR animals, we found a higher PLIN1 protein than in the D-CTR group. PLIN1 is known to be expressed only in adipocytes and macrophages [35]. PLIN1 plays a key role in the lipolysis of intracellular lipid deposits [35] and there may be significant associations between proteins that regulate fat metabolism and skeletal integrity. In fact, in bone, matrix vesicles are thought to arise by budding from the osteoblast plasma membrane containing high levels of cholesterol and other lipids, which ultimately result in the nucleation and propagation of mineral crystals [58]. However, Yamada et al. [59] studied a PLIN1 single-nucleotide polymorphism (SNP) and its relationship to BMD. They found that the $1243 \mathrm{C} \rightarrow \mathrm{T}$ polymorphism was associated with BMD at several sites in men, with the $\mathrm{C}$ allele being related to reduced BMD. Future research is necessary to confirm the role of PLIN1 in macrophages differentiation as well as bone biology.

Another intriguing finding was that C-peptide administration prevented the red cells and haemoglobin reduction seen in D-CRT (Table 2). Thus, a potential effect of C-peptide on bone marrow could be assumed [13]. There is a close relationship between haematopoiesis and bone formation. Anaemia may be more common in diabetes [60]. Haemoglobin levels are positively associated with BMD in the elderly, and anaemia is one of the risk factors for bone loss [61]. Mice deficient in Cbfa1/Runx2, a transcription factor crucial for osteoblast progression, did not develop osteoblasts and had empty bone marrow [62]. Osteoblasts are located at the endosteal bone surface just next to the hematopoietic stem cells (HSCs) in the bone marrow [63]. By producing several growth factors, osteoblasts increase the number of HSCs [64]. We hypothesize, thus, that C-peptide could stimulate bone marrow-derived cells differentiation. Of course, we cannot confirm that this effect improves the trabecular bone. All these results need confirmatory research.

Another interesting finding relate to RANKL. In our study, C-PEP had a higher serum RANKL than D-CRT (Table 4). Since RANKL is expressed preferably by undifferentiated osteoblasts, this finding could reflect an increase in the number of active osteoblasts with the C-peptide therapy, as seen with Teriparatide [65]. In line with this concept, we found a negative correlation between Tb.Sp (assessed by both micro-CT and histomorphometry) and RANK-L (Table 3).

In our study C-peptide therapy was associated with both a high serum phosphorus and calcium concentration (Table 1). Rats received the same feeding schedule, thus, as observed with risedronate [66], our finding may confirm the direct role of C-peptide in the high bone turnover rate.

Although it is important to highlight the role of bone collagen in providing the matrix for bone mineralization and conferring bone elasticity, we found no association between COLIA1 or BSP and C-peptide concentration. Nor did we found a significant difference of COLIA1 or BSP, histologically assessed, between groups. Again, the study duration and/or the bone district analysed, likely affected these results.

In our study, other limitations should be acknowledged. We used a STZ-injected male rats model; however, the effects in females could be different; thus, the applicability of these results could be limited and could have affected our results.

Unfortunately, due to an electrical problem and the consequent partial loss of rats organs and tissues, we did not perform tibia measurements of the bone microarchitectural parameters. However, the potential clinical significance of $\mathrm{C}$-peptide in osteoporosis is highlighted by all the present results.

\section{Conclusion}

This study, for the first time, demonstrated that the diabetic rats receiving rat C-peptide had higher quality of trabecular bone, represented by higher trabecular thickness, crosssectional thickness, lower trabecular spaces and higher RUNX-2 protein in the femur, than diabetic rats not receiving this replacement therapy. In addition, C-peptide therapy increased serum calcium and tibia weight. Finally, C-peptide administration prevented both the red cells and haemoglobin reduction seen in diabetic rats. Further studies are necessary to confirm and clarify all these findings. However, in line with previous cross-sectional investigations carried out in postmenopausal women as well as in vitro observations, 
this study suggests a role of C-peptide in improving bone microarchitectural parameters, at least in T1DM.

Acknowledgement We are grateful to Dr John Wahren, from Karolinska Institutet, Stockholm, Sweden, for providing Rat C-Peptide.

Author Contributions SM, CR, MG, MS, FB, EM contributed to the experimental work. SM, CR and VM are guarantor of the integrity of the data; VM and SN performed microCT assessment; RP was responsible for the glucose monitoring and insulin injection planning; MTV, MD, SG and LDC performed the histological assessment; VMM, MR and DB performed all the laboratory measurements; SR, VM, AP and TM designed the study and prepared the first draft of the paper. TM and CG were responsible for statistical analysis of the data. All authors revised the paper critically for intellectual content and approved the final version.

Funding This research did not receive any specific grant from funding agencies in the public, commercial, or not-for-profit sectors.

\section{Compliance with Ethical Standards}

Conflict of interest All authors declared there were no conflict of interests involved.

Ethical Approval The experiments were carried out following the European guidelines (2010/63/EU) regarding procedures with animals used, in accordance with the approval of the Ethics Committee for Experimental Animals Welfare of the University Magna Grecia, Catanzaro (Auth. 10/01/2018) and Italian Ministry of Health (Auth. No 353/2018-protocol ADEAB.16, Auth. 9/05/2018).

\section{References}

1. Forsén L, Meyer HE, Midthjell K, Edna TH (1999) Diabetes mellitus and the incidence of hip fracture: results from the NordTrøndelag Health Survey. Diabetologia 42(8):920-925. https:// doi.org/10.1007/s001250051248

2. Léger J, Marinovic D, Alberti C, Dorgeret S, Chevenne D, Marchal CL, Tubiana-Rufi N, Sebag G, Czernichow P (2006) Lower bone mineral content in children with type 1 diabetes mellitus is linked to female sex, low insulin-like growth factor type I levels, and high insulin requirement. J Clin Endocrinol Metab 91(10):3947-3953. https://doi.org/10.1210/jc.2006-0711

3. Gunczler P, Lanes R, Paz-Martinez V, Martins R, Esaa S, Colmenares V, Weisinger JR (1998) Decreased lumbar spine bone mass and low bone turnover in children and adolescents with insulin dependent diabetes mellitus followed longitudinally. J Pediatric Endocrinol Metab JPEM 11(3):413-419. https://doi.org/10.1515/ jpem.1998.11.3.413

4. Levin ME, Boisseau VC, Avioli LV (1976) Effects of diabetes mellitus on bone mass in juvenile and adult-onset diabetes. $\mathrm{N}$ Engl J Med 294(5):241-245. https://doi.org/10.1056/NEJM1 97601292940502

5. Inzerillo AM, Epstein S (2004) Osteoporosis and diabetes mellitus. Rev Endocr Metab Disorders 5(3):261-268. https://doi. org/10.1023/B:REMD.0000032415.83124.20

6. Margeirsdottir HD, Stensaeth KH, Larsen JR, Brunborg C, DahlJørgensen K (2010) Early signs of atherosclerosis in diabetic children on intensive insulin treatment: a population-based study. Diabetes Care 33(9):2043-2048. https://doi.org/10.2337/dc10-0505
7. Costacou T, Lopes-Virella MF, Zgibor JC, Virella G, Otvos J, Walsh M, Orchard TJ (2005) Markers of endothelial dysfunction in the prediction of coronary artery disease in type 1 diabetes. The Pittsburgh Epidemiology of Diabetes Complications Study. J Diabetes Its Complicat 19(4):183-193. https://doi.org/10.1016/j. jdiacomp.2005.01.003

8. Campos Pastor MM, López-Ibarra PJ, Escobar-Jiménez F, Serrano Pardo MD, García-Cervigón AG (2000) Intensive insulin therapy and bone mineral density in type 1 diabetes mellitus: a prospective study. Osteoporosis Int 11(5):455-459. https://doi.org/10.1007/ s001980070114

9. Nicodemus KK, Folsom AR, Iowa Women's Health Study (2001) Type 1 and type 2 diabetes and incident hip fractures in postmenopausal women. Diabetes Care 24(7):1192-1197. https://doi. org/10.2337/diacare.24.7.1192

10. Vestergaard P (2007) Discrepancies in bone mineral density and fracture risk in patients with type 1 and type 2 diabetes-a metaanalysis. Osteoporosis Int 18(4):427-444. https://doi.org/10.1007/ s00198-006-0253-4

11. Lu H, Kraut D, Gerstenfeld LC, Graves DT (2003) Diabetes interferes with the bone formation by affecting the expression of transcription factors that regulate osteoblast differentiation. Endocrinology 144(1):346-352. https://doi.org/10.1210/en.2002-22007 2

12. Montalcini T, Romeo S, Ferro Y, Migliaccio V, Gazzaruso C, Pujia A (2013) Osteoporosis in chronic inflammatory disease: the role of malnutrition. Endocrine 43(1):59-64. https://doi. org/10.1007/s12020-012-9813-x

13. Suzuki K, Sugimoto C, Takizawa M, Ishizuka S, Kikuyama M, Togawa H, Taguchi Y, Nosaka K, Seino Y, Ishida H (2000) Correlations between bone mineral density and circulating bone metabolic markers in diabetic patients. Diabetes Res Clin Pract 48(3):185-191. https://doi.org/10.1016/s0168-8227(00)00119-4

14. Ekberg K, Brismar T, Johansson BL, Lindström P, Juntti-Berggren L, Norrby A, Berne C, Arnqvist HJ, Bolinder J, Wahren J (2007) C-Peptide replacement therapy and sensory nerve function in type 1 diabetic neuropathy. Diabetes Care 30(1):71-76. https:// doi.org/10.2337/dc06-1274

15. Steiner DF, Cunningham D, Spigelman L, Aten B (1967) Insulin biosynthesis: evidence for a precursor. Science (New York, NY) 157(3789):697-700. https://doi.org/10.1126/scien ce.157.3789.697

16. Hoogwerf BJ, Bantle JP, Gaenslen HE, Greenberg BZ, Senske BJ, Francis R, Goetz FC (1986) Infusion of synthetic human C-peptide does not affect plasma glucose, serum insulin, or plasma glucagon in healthy subjects. Metabolism 35(2):122-125. https ://doi.org/10.1016/0026-0495(86)90111-3

17. Ekberg K, Brismar T, Johansson BL, Jonsson B, Lindström P, Wahren J (2003) Amelioration of sensory nerve dysfunction by C-Peptide in patients with type 1 diabetes. Diabetes 52(2):536541. https://doi.org/10.2337/diabetes.52.2.536

18. Wahren J, Ekstrom U, Ekberg K (2011) C-peptide improves erectile function in type 1 diabetes. Diabetes 60:A285-A285

19. Hansen A, Johansson BL, Wahren J, von Bibra H (2002) C-peptide exerts beneficial effects on myocardial blood flow and function in patients with type 1 diabetes. Diabetes 51(10):3077-3082. https://doi.org/10.2337/diabetes.51.10.3077

20. Forst T, Kunt T, Pohlmann T, Goitom K, Engelbach M, Beyer J, Pfützner A (1998) Biological activity of C-peptide on the skin microcirculation in patients with insulin-dependent diabetes mellitus. J Clin Investig 101(10):2036-2041. https://doi.org/10.1172/ JCI2147

21. Montalcini T, Gallotti P, Coppola A, Zambianchi V, Fodaro M, Galliera E, Marazzi MG, Romeo S, Giannini S, Corsi Romanelli MM, Pujia A, Gazzaruso C (2015) Association between low $\mathrm{C}$-peptide and low lumbar bone mineral density 
in postmenopausal women without diabetes. Osteoporos Int 26(5):1639-1646. https://doi.org/10.1007/s00198-015-3040-2

22. Ferro Y, Russo C, Russo D, Gazzaruso C, Coppola A, Gallotti P, Zambianchi V, Fodaro M, Romeo S, Galliera E, Marazzi MG, Romanelli MMC, Giannini S, Pujia A, Montalcini T (2017) Association between low C-peptide and fragility fractures in postmenopausal women without diabetes. J Endocrinol Invest 40(10):1091-1098. https://doi.org/10.1007/s40618-017-0672-4

23. Russo C, Lazzaro V, Gazzaruso C, Maurotti S, Ferro Y, Pingitore P, Fumo F, Coppola A, Gallotti P, Zambianchi V, Fodaro M, Galliera E, Marazzi MG, Corsi Romanelli MM, Giannini S, Romeo S, Pujia A, Montalcini T (2017) Proinsulin C-peptide modulates the expression of ERK1/2, type I collagen and RANKL in human osteoblast-like cells (Saos-2). Mol Cell Endocrinol 442:134-141. https://doi.org/10.1016/j. mce.2016.12.012

24. Horcajada-Molteni MN, Chanteranne B, Lebecque P, Davicco MJ, Coxam V, Young A, Barlet JP (2001) Amylin and bone metabolism in streptozotocin-induced diabetic rats. J Bone Miner Res 16(5):958-965. https://doi.org/10.1359/jbmr.2001.16.5.958

25. Robey PG (1996) Vertebrate mineralized matrix proteins: structure and function. Connect Tissue Res 35(1-4):131-136. https:// doi.org/10.3109/03008209609029183

26. Ingram RT, Clarke BL, Fisher LW, Fitzpatrick LA (1993) Distribution of noncollagenous proteins in the matrix of adult human bone: evidence of anatomic and functional heterogeneity. J Bone Miner Res 8(9):1019-1029. https://doi.org/10.1002/jbmr.56500 80902

27. Anderson HC (2003) Matrix vesicles and calcification. Curr Rheumatol Rep 5(3):222-226. https://doi.org/10.1007/s1192 6-003-0071-z

28. Chen X, Goodman JM (2017) The collaborative work of droplet assembly. Biochim Biophys Acta Mol Cell Biol Lipids 1862(10):1205-1211. https://doi.org/10.1016/j.bbali p.2017.07.003

29. Samnegård B, Jacobson SH, Johansson BL, Ekberg K, Isaksson B, Wahren J, Sjöquist M (2004) C-peptide and captopril are equally effective in lowering glomerular hyperfiltration in diabetic rats. Nephrol Dialysis Transpl 19(6):1385-1391. https://doi. org/10.1093/ndt/gfh163

30. Bouxsein ML, Boyd SK, Christiansen BA, Guldberg RE, Jepsen KJ, Müller R (2010) Guidelines for assessment of bone microstructure in rodents using micro-computed tomography. J Bone Miner Res 25(7):1468-1486. https://doi.org/10.1002/jbmr.141

31. Ito M, Nakamura T, Matsumoto T, Tsurusaki K, Hayashi K (1998) Analysis of trabecular microarchitecture of human iliac bone using microcomputed tomography in patients with hip arthrosis with or without vertebral fracture. Bone 23(2):163-169. https:// doi.org/10.1016/s8756-3282(98)00083-0

32. DalleCarbonare L, Valenti MT, Bertoldo F, Zanatta M, Zenari S, Realdi G, LoCascio V, Giannini S (2005) Bone microarchitecture evaluated by histomorphometry. Micron (Oxford, England: 1993) 36(7-8):609-616. https://doi.org/10.1016/j.micron.2005.07.007

33. Dempster DW, Compston JE, Drezner MK, Glorieux FH, Kanis JA, Malluche H, Meunier PJ, Ott SM, Recker RR, Parfitt AM (2013) Standardized nomenclature, symbols, and units for bone histomorphometry: a 2012 update of the report of the ASBMR Histomorphometry Nomenclature Committee. J Bone Miner Res 28(1):2-17. https://doi.org/10.1002/jbmr.1805

34. Valenti MT, Giannini S, Donatelli L, Zanatta M, Bertoldo F, Sella S, Vilei MT, Ossi E, Realdi G, Lo Cascio V, Dalle Carbonare L (2010) The effect of risedronate on osteogenic lineage is mediated by cyclooxygenase- 2 gene upregulation. Arthritis Res Therapy 12(4):R163. https://doi.org/10.1186/ar3122

35. Greenberg AS, Egan JJ, Wek SA, Garty NB, Blanchette-Mackie EJ, Londos C (1991) Perilipin, a major hormonally regulated adipocyte-specific phosphoprotein associated with the periphery of lipid storage droplets. J Biol Chem 266(17):11341-11346

36. Gurel Pekozer G, Ramazanoglu M, Schlegel KA, Kok FN, Torun Kose G (2018) Role of STRO-1 sorting of porcine dental germ stem cells in dental stem cell-mediated bone tissue engineering. Artificial Cells Nanomed Biotechnol 46(3):607-618. https://doi. org/10.1080/21691401.2017.1332637

37. Müller R, van Lenthe H (2004) Microarchitectural aspects of quality and competence of bone. Adv Osteoporotic Fract Manag 3:2-12

38. Chen P, Jerome CP, Burr DB, Turner CH, Ma YL, Rana A, Sato $M$ (2007) Interrelationships between bone microarchitecture and strength in ovariectomized monkeys treated with teriparatide. J Bone Miner Res 22(6):841-848. https://doi.org/10.1359/ jbmr.070310

39. Doube M, Klosowski MM, Wiktorowicz-Conroy AM, Hutchinson JR, Shefelbine SJ (2011) Trabecular bone scales allometrically in mammals and birds. Proc Biol Sci 278(1721):3067-3073. https ://doi.org/10.1098/rspb.2011.0069

40. Johansson BL, Sjöberg S, Wahren J (1992) The influence of human C-peptide on renal function and glucose utilization in type 1 (insulin-dependent) diabetic patients. Diabetologia 35(2):121128. https://doi.org/10.1007/BF00402543

41. Johansson BL, Borg K, Fernqvist-Forbes E, Kernell A, Odergren T, Wahren J (2000) Beneficial effects of C-peptide on incipient nephropathy and neuropathy in patients with Type 1 diabetes mellitus. Diabetic Med 17(3):181-189. https://doi.org/10.104 6/j.1464-5491.2000.00274.x

42. Johansson BL, Linde B, Wahren J (1992) Effects of C-peptide on blood flow, capillary diffusion capacity and glucose utilization in the exercising forearm of type 1 (insulin-dependent) diabetic patients. Diabetologia 35(12):1151-1158. https://doi.org/10.1007/ BF00401369

43. Gao X, Ma W, Dong H, Yong Z, Su R (2014) Establishing a rapid animal model of osteoporosis with ovariectomy plus low calcium diet in rats. Int J Clin Exp Pathol 7(8):5123-5128

44. Enríquez-Pérez IA, Galindo-Ordoñez KE, Pantoja-Ortíz CE, Martínez-Martínez A, Acosta-González RI, Muñoz-Islas E, Jiménez-Andrade JM (2017) Streptozocin-induced type-1 diabetes mellitus results in decreased density of CGRP sensory and TH sympathetic nerve fibers that are positively correlated with bone loss at the mouse femoral neck. Neurosci Lett 655:28-34. https:// doi.org/10.1016/j.neulet.2017.06.042

45. Ferretti M, Cavani F, Roli L, Checchi M, Magarò MS, Bertacchini J, Palumbo C (2019) Interaction among calcium diet content, PTH (1-34) treatment and balance of bone homeostasis in rat model: the trabecular bone as keystone. Int J Mol Sci 20(3):753. https:// doi.org/10.3390/ijms20030753

46. Nyman JS (2013) Effect of diabetes on the fracture resistance of bone. Clin Rev Bone Miner Metab 11(1):38-48

47. Colaianni G, Cuscito C, Mongelli T, Pignataro P, Buccoliero C, Liu P, Lu P, Sartini L, Di Comite M, Mori G, Di Benedetto A, Brunetti G, Yuen T, Sun L, Reseland JE, Colucci S, New MI, Zaidi M, Cinti S, Grano M (2015) The myokine irisin increases cortical bone mass. Proc Natl Acad Sci USA 112(39):1215712162. https://doi.org/10.1073/pnas.1516622112

48. Bortolin RH, Freire Neto FP, Arcaro CA, Bezerra JF, da Silva FS, Ururahy MA, Souza KS, Lima VM, Luchessi AD, Lima FP, Lia Fook MV, da Silva BJ, Almeida MD, Abreu BJ, de Rezende LA, de Rezende AA (2017) Anabolic effect of insulin therapy on the bone: osteoprotegerin and osteocalcin up-regulation in streptozotocin-induced diabetic rats. Basic Clin Pharmacol Toxicol 120(3):227-234. https://doi.org/10.1111/bcpt.12672

49. Milovanovic P, Stojanovic M, Antonijevic D, Cirovic A, Radenkovic M, Djuric M (2018) "Dangerous duo": Chronic nicotine exposure intensifies diabetes mellitus-related deterioration in bone 
microstructure — an experimental study in rats. Life Sci 212:102108. https://doi.org/10.1016/j.lfs.2018.09.044

50. Hua Y, Bi R, Zhang Y, Xu L, Guo J, Li Y (2018) Different bone sites-specific response to diabetes rat models: bone density, histology and microarchitecture. PLoS ONE 13(10):e0205503. https:// doi.org/10.1371/journal.pone.0205503

51. Schuit SC, van der Klift M, Weel AE, de Laet CE, Burger H, Seeman E, Hofman A, Uitterlinden AG, van Leeuwen JP, Pols HA (2004) Fracture incidence and association with bone mineral density in elderly men and women: the Rotterdam Study. Bone 34(1):195-202. https://doi.org/10.1016/j.bone.2003.10.001

52. Stone KL, Seeley DG, Lui LY, Cauley JA, Ensrud K, Browner WS, Nevitt MC, Osteoporotic Fractures Research Group (2003) BMD at multiple sites and risk of fracture of multiple types: long-term results from the Study of Osteoporotic Fractures. J Bone Miner Res 18(11):1947-1954. https://doi.org/10.1359/ jbmr.2003.18.11.1947

53. Yeni YN, Brown CU, Wang Z, Norman TL (1997) The influence of bone morphology on fracture toughness of the human femur and tibia. Bone 21(5):453-459. https://doi.org/10.1016/s8756 -3282(97)00173-7

54. Martin RB (1984) Porosity and specific surface of bone. Crit Rev Biomed Eng 10(3):179-222

55. Sornay-Rendu E, Boutroy S, Duboeuf F, Chapurlat RD (2017) Bone microarchitecture assessed by HR-pQCT as predictor of fracture risk in postmenopausal women: The OFELY Study. J Bone Miner Res 32(6):1243-1251. https://doi.org/10.1002/ jbmr.3105

56. Shanbhogue VV, Hansen S, Frost M, Jørgensen NR, Hermann AP, Henriksen JE, Brixen K (2015) Bone geometry, volumetric density, microarchitecture, and estimated bone strength assessed by HR-pQCT in adult patients with type 1 diabetes mellitus. J Bone Miner Res 30(12):2188-2199. https://doi.org/10.1002/jbmr.2573

57. Shanbhogue VV, Hansen S, Frost M, Jørgensen NR, Hermann AP, Henriksen JE, Brixen K (2016) Compromised cortical bone compartment in type 2 diabetes mellitus patients with microvascular disease. Eur J Endocrinol 174(2):115-124. https://doi. org/10.1530/EJE-15-0860

58. Golub EE (2009) Role of matrix vesicles in biomineralization. Biochem Biophys Acta 1790(12):1592-1598. https://doi. org/10.1016/j.bbagen.2009.09.006

59. Yamada Y, Ando F, Shimokata H (2006) Association of polymorphisms in forkhead box $\mathrm{C} 2$ and perilipin genes with bone mineral density in community-dwelling Japanese individuals. Int J Mol Med 18(1):119-127

60. Thomas MC, MacIsaac RJ, Tsalamandris C, Power D, Jerums G (2003) Unrecognized anemia in patients with diabetes: a crosssectional survey. Diabetes Care 26(4):1164-1169. https://doi. org/10.2337/diacare.26.4.1164

61. Laudisio A, Marzetti E, Pagano F, Bernabei R, Zuccalà G (2009) Haemoglobin levels are associated with bone mineral density in the elderly: a population-based study. Clin Rheumatol 28(2):145151. https://doi.org/10.1007/s10067-008-0998-6

62. Komori T, Yagi H, Nomura S, Yamaguchi A, Sasaki K, Deguchi K, Shimizu Y, Bronson RT, Gao YH, Inada M, Sato M, Okamoto R, Kitamura Y, Yoshiki S, Kishimoto T (1997) Targeted disruption of Cbfa1 results in a complete lack of bone formation owing to maturational arrest of osteoblasts. Cell 89(5):755-764. https:// doi.org/10.1016/s0092-8674(00)80258-5

63. Calvi LM, Adams GB, Weibrecht KW, Weber JM, Olson DP, Knight MC, Martin RP, Schipani E, Divieti P, Bringhurst FR, Milner LA, Kronenberg HM, Scadden DT (2003) Osteoblastic cells regulate the haematopoietic stem cell niche. Nature 425(6960):841-846. https://doi.org/10.1038/nature02040

64. Zhang J, Niu C, Ye L, Huang H, He X, Tong WG, Ross J, Haug J, Johnson T, Feng JQ, Harris S, Wiedemann LM, Mishina Y, Li $\mathrm{L}$ (2003) Identification of the haematopoietic stem cell niche and control of the niche size. Nature 425(6960):836-841. https://doi. org/10.1038/nature02041

65. Anastasilakis AD, Goulis DG, Polyzos SA, Gerou S, Pavlidou V, Koukoulis G, Avramidis A (2008) Acute changes in serum osteoprotegerin and receptor activator for nuclear factor-kB ligand levels in women with established osteoporosis treated with teriparatide. Eur J Endocrinol 158(3):411-416

66. Shiraki M, Fukunaga M, Kushida K, Kishimoto H, Taketani Y, Minaguchi H, Inoue T, Morita R, Morii H, Yamamoto K, Ohashi Y, Orimo H (2003) A double-blind dose-ranging study of risedronate in Japanese patients with osteoporosis (a study by the Risedronate Late Phase II Research Group). Osteoporosis Int 14(3):225-234. https://doi.org/10.1007/s00198-002-1369-9

Publisher's Note Springer Nature remains neutral with regard to jurisdictional claims in published maps and institutional affiliations.

\section{Affiliations}

\section{Samantha Maurotti ${ }^{1}$. Cristina Russo ${ }^{2}$ - Vincenzo Musolino ${ }^{3}$. Saverio Nucera ${ }^{3}$. Micaela Gliozzi ${ }^{3}$. Miriam Scicchitano ${ }^{3}$. Francesca Bosco ${ }^{3}$. Valeria Maria Morittu ${ }^{4}$. Monica Ragusa ${ }^{4}$ Elisa Mazza ${ }^{1} \cdot$ Roberta Pujia $^{1}$. Carmine Gazzaruso ${ }^{5}$. Domenico Britti ${ }^{4} \cdot$ Maria Teresa Valenti $^{6} \cdot$ Michela Deiana $^{6,7} \cdot$ Stefano Romeo ${ }^{1,8}$. Sandro Giannini ${ }^{9} \cdot$ Luca Dalle Carbonare $^{6} \cdot$ Vincenzo Mollace $^{3} \cdot$ Arturo Pujia $^{1} \cdot$ Tiziana Montalcini $^{2}{ }^{10}$}

\author{
Samantha Maurotti \\ smaurotti@unicz.it \\ Cristina Russo \\ crusso@unicz.it \\ Saverio Nucera \\ saverio.nucera@hotmail.it \\ Micaela Gliozzi \\ micaela.gliozzi@gmail.com \\ Miriam Scicchitano \\ miriam.scicchitano@hotmail.it
}

Francesca Bosco

boscofrancesca.bf@libero.it

Valeria Maria Morittu

morittu@unicz.it

Monica Ragusa

m.ragusa@unicz.it

Elisa Mazza

elisamazza@inwind.it

Roberta Pujia

roberta.puj@gmail.com; pujia@unicz.it 
Carmine Gazzaruso

c.gazzaruso@gmail.it

Domenico Britti

britti@unicz.it

Maria Teresa Valenti

mariateresa.valenti@univr.it

Michela Deiana

michela.deiana@univr.it

Stefano Romeo

romeo@unicz.it

Sandro Giannini

sandro.giannini@unipd.it

Luca Dalle Carbonare

luca.dallecarbonare@univr.it

Vincenzo Mollace

mollace@libero.it

Arturo Pujia

pujia@unicz.it

1 Department of Medical and Surgical Science, Magna Græcia University of Catanzaro, 88100 Catanzaro, Italy
2 Department of Clinical and Experimental Medicine, Magna Græcia University of Catanzaro, Viale S. Venuta, 88100 Catanzaro, Italy

3 IRC-FSH Interregional Center for Food Safety and Health, Department of Health Sciences, Magna Græcia University of Catanzaro, Catanzaro, Italy

4 Department of Health Sciences, Magna Græcia University of Catanzaro, Catanzaro, Italy

5 Diabetes and Endocrine and Metabolic Diseases Unit and the Centre for Applied Clinical Research (Ce.R.C.A.) Clinical Institute "Beato Matteo" (Hospital Group San Donato), 27029 Vigevano, Italy

6 Department of Medicine, Specialized Regional Center for Biomolecular and Histomorphometric Research On Degenerative and Skelatal Diseases, Verona, Italy

7 Department of Neurosciences, Biomedicine and Movement Sciences, University of Verona, 37134 Verona, Italy

8 Department of Molecular and Clinical Medicine, Sahlgrenska Center for Cardiovascolar and Metabolic Research, University of Gothenburg, 42246 Göteborg, Sweden

9 Department of Medicine, University of Padova and Regional Center for Osteoporosis, Clinica Medica 1, Padova, Italy 